Apresentação | Introduction

\title{
Governança reprodutiva: um assunto de suma relevância política
}

\section{Reproductive governance: a matter of utmost political relevance}

\author{
Claudia Fonsecal \\ https://orcid.org/0000-0002-7761-6095 \\ claudialwfonseca@gmail.com \\ Diana Marre" \\ https://orcid.org/0000-0003-2852-3762 \\ diana.marre@uab.es
}

Fernanda Rifiotis'

https://orcid.org/0000-0002-7307-2254

frifiotis@gmail.com

' Universidade Federal do Rio Grande do Sul - Porto Alegre, RS, Brasil

" Universitat Autònoma de Barcelona - Barcelona, Catalunha, Espanha 
No fim de julho, 2021, uma notícia publicada em um jornal de Florianópolis narra o caso de uma bebê que, antes mesmo de completar seu primeiro mês de vida, foi retirada da sua mãe e encaminhada para um abrigo e, posteriormente, teria sido hospitalizada por ter apresentado problemas com a alimentação feita com fórmula em substituição ao leite materno. À medida que se avança na leitura do texto, ${ }^{1}$ uma trama complexa de eventos vai sendo revelada e nos interpela de muitas formas. A mãe, Andrielli - uma jovem negra de 21 anos -, estava proibida de ter contato e amamentar a filha, que lhe foi retirada pelo conselho tutelar apenas três horas após o parto. Na véspera da internação, o desembargador havia negado o recurso impetrado pelo defensor público para que a mãe pudesse ter contato com a filha e a amamentasse. A justificativa para essa separação entre mãe e filha estaria no fato de a jovem enfrentar um processo de destituição do poder familiar, cujo desfecho decidirá a quem cabe a guarda da criança. No processo estariam supostas violações de direitos da criança e a "negligência" por parte da mãe durante a gravidez. No histórico da mãe, mencionado pelo conselho tutelar, constariam também outros dois processos de destituição do poder familiar e a vida em situação de rua durante a gestação. Ao final do texto, em um último ato, a jovem torna-se vítima de uma possível violência obstétrica cometida pelo hospital. A defensoria pública estaria apurando a realização de uma laqueadura sem consentimento e também aponta para irregularidade após o parto com a proibição da amamentação, direito da mãe, previsto em lei.

Ao trazermos o caso de Andrielli pretendemos mostrar o quanto ele nos fala sobre práticas e pautas que já nos são conhecidas e nos interpelam diariamente. A história dessa mãe jovem nos fala sobre maternidade, família (e destituição do poder familiar), tutela (guarda e institucionalização), cuidado (quem pode cuidar e quem merece ser cuidado), parto e violência obstétrica, esterilização feminina (laqueadura sem consentimento), direitos reprodutivos (direito de amamentar, direito de escolha), violação de direitos (da mãe e do bebê), reprodução estratificada (famílias que são reconhecidas e legítimas e aquelas que são objeto de uma constante vigilância punitiva) e pobreza e desigualdade social. Ao mesmo tempo, é importante notar que não faltaram

1 Reportagem publicada no site jornalístico Catarinas em 30 de julho de 2021 (Guimarães, 2021). E, posteriormente, em 21 de agosto de 2021, a notícia foi veiculada no jornal $N D+$ (Bottamedi, 2021). 
reações em diferentes escalas contra o tipo de abuso que ocorreu com Andrielli desde as denúncias mediáticas, protestos de movimentos sociais (em particular, do movimento negro - já que tantos casos envolvem mães não brancas), audiências públicas, pesquisas acadêmicas coordenadas e até uma nota da própria Associação Brasileira de Antropologia (ABA). Essas reações assinalam não só brechas nos desenhos modernistas de controle, mas também o potencial de protestos coletivos e a própria agência das pessoas envolvidas.

Ao iniciar nossa discussão com esse caso, nossa intenção é de sublinhar como, muito além de ser um fenômeno biológico bem delimitado, a reprodução humana está inevitavelmente entrelaçada com interesses de coletividades e forças políticas que perpassam o tecido social. Representa um problema tanto material quanto político perpassado por questões não só de gênero e sexualidade, mas também de Estado, raça e mercado que, via corpos e afetos, interconectam o micrológico com processos transnacionais (Murphy, 2012). Assim, a história de Andrielli reúne uma série de eventos passiveis de problematização à luz da temática do presente número: a Governança Reprodutiva, termo consagrado, em 2012, pela dupla de antropólogas feministas Lynn Morgan e Elizabeth Roberts:

Os mecanismos pelos quais diferentes configurações históricas de atores, como instituições estatais, religiosas e internacionais financeiras, ONGs e movimentos sociais, usam controles legislativos, incentivos econômicos, injunções morais, coerção direta e incitamentos éticos para produzir, monitorar e controlar comportamentos reprodutivos e práticas populacionais. (Morgan; Roberts, 2012, p. 243, tradução nossa).

Assumimos que, ao focar a governança reprodutiva, estamos cobrindo apenas uma modesta parte do vasto campo da antropologia da reprodução (Grossi; Oltramari; Ferreira, 2021; Han; Tomori, 2021). Porém, a partir dos textos selecionados para compor este número, buscamos revigorar alguns debates que vêm se delineando em anos recentes sobre reprodução estratificada, regimes morais, cuidado/trabalho reprodutivo e agência/ação transformativa. Reunimos sob uma mesma pauta estudos que têm sido pensados de forma etnográfica sobre processos reprodutivos - da saúde da mulher e gravidez até as diferentes formas do exercício materno - em diversos países e com diferentes ênfases. Partimos 
da hipótese de que toda reprodução é política (Ginsburg; Rapp, 1995) e, seguindo a trajetória de debates dos últimos anos, esperamos chegar à demonstração de que, tal como sugere Briggs (2017), todas as políticas são políticas reprodutivas.

Para a organização deste número de Horizontes Antropológicos, contamos com a colaboração de três pesquisadoras - uma norte-americana radicada há décadas no Brasil, uma argentina morando há 30 anos na Espanha e uma brasileira com vivência na França, além de pareceristas de vários países da América do Sul e também da Europa. ${ }^{2}$ Dessa maneira, pudemos aprofundar uma reflexão sobre os múltiplos fenômenos ligados ao campo da reprodução a partir da comparação tácita entre regiões (Norte e Sul; Europa-Estados Unidos e América Latina) e entre países (com maior ênfase no Cone Sul e na Espanha), com ampla consideração dos fluxos globais. Não pretendemos dar conta da vasta produção que existe nesse campo (ver Han; Tomori, 2021), mas nos parágrafos a seguir, depois de acenar para a linha de análise que inspirou nosso foco na governança reprodutiva, esboçamos algumas ideias que emergiram através do diálogo com as autoras e os autores e pareceristas deste volume.

\section{Emaranhados entre feminismo e direitos reprodutivos}

A linha analítica que nos interessa aqui começa recentemente, nos emaranhados entre feminismo e direitos reprodutivos. Embora suscitada já no final dos anos 1960 pela Comissão de Direitos Humanos da ONU, foi a Conferência do Cairo que consagrou a ideia de direitos reprodutivos em 1994 para se referir ao bem-estar completo, físico e mental, em todos os processos e funções relacionadas ao sistema reprodutivo. No mesmo ano, o Black Women's Caucus, em Chicago, acrescentou uma nova dimensão fundamental às discussões, se referindo à justiça reprodutiva. Segundo essa noção, tão importante quanto o direito a não ter filhos era o direito a ter e criar filhos em condições dignas. A noção de governança reprodutiva tem suas raízes nessa conjuntura histórica, forjada pela

2 Claudia Fonseca conta com o apoio financeiro do CNPq (Conselho Nacional de Desenvolvimento Científico e Tecnológico) na forma de uma bolsa de produtividade em pesquisa; Diana Marre participou como IP do projeto PID2020-112692RB-C21/AEI/10.13039/501100011033 financiado pelo Ministerio de Ciencia, Innovación y Universidades de España e graças ao prêmio ICREA Acadèmia que recebeu para o período 2020-2024. 
convergência de diversos movimentos sociais (feminista, negro, LGBTT, descolonialista) e seus tremendos esforços para levar adiante certa agenda política.

As bases conceituais para uma antropologia da reprodução foram articuladas nos trabalhos pioneiros de Rayna Rapp e Faye Ginsburg durante os anos 1990, indo do primeiro enunciado em "The politics of reproduction" (Ginsburg; Rapp, 1991) até uma consolidação da proposta na introdução da coletânea, Conceiving the New World Order: the global politics of reproduction (Ginsburg; Rapp, 1995) [Concebendo a Nova Ordem Mundial: políticas globais de reprodução]. Com o objetivo assumido de romper com preconcepções que tinham relegado a reprodução a uma esfera restrita - exclusivamente doméstica, biológica e basicamente feminina -, as autoras apresentavam a reprodução como assunto sumamente político. As controvérsias sobre práticas reprodutivas diziam respeito a lutas sobre o futuro de comunidades, nações e povos. Reafirmando o espírito que tinha permeado as diversas conferências mundiais (Cairo, Beijing, etc.), as colaboradoras daquele volume mostravam o fluxo transnacional de tecnologias, ideologias e normas que interagiam, num terreno altamente desigual, com "culturas" e práticas locais. E denunciavam os instrumentos de violência eufemizada - lacunas, silêncios e discursos filantrópicos, que contribuíam para invisibilizar o enorme valor econômico, político e emocional do trabalho reprodutivo.

Reforçando a ideia de desigualdades no campo da reprodução, a noção de "reprodução estratificada" foi cunhada para sublinhar a distribuição desproporcional de trabalho reprodutivo nas dinâmicas que interconectam diferentes grupos, fazendo com que algumas pessoas acabem desfrutando de um grande leque de possibilidades à custa de outras. Shellee Colen (1995), autora do conceito, ilustrou a estratificação simbiótica de modelos de família com o caso de babás caribenhas em Nova Iorque que, enquanto se esmeravam em cuidar dos filhos da elite norte-americana, observavam à distância seus próprios filhos crescerem em circunstâncias longe de ideais. Mas a noção de reprodução estratificada seria logo aplicada a um grande leque de práticas reprodutivas - de adoções transnacionais a maternidades sub-rogadas - para ressaltar como as desigualdades de dinheiro e poder condicionam as relações complementares e hierárquicas nas dinâmicas reprodutivas contemporâneas.

Ao introduzir o tema da governança reprodutiva, Morgan e Roberts (2012) procuraram consolidar as novas tendências analíticas reforçando alguns 
caminhos indicados por Ginsburg e Rapp (1991). Assim, propuseram estender o olhar analítico para além do Estado (para forças políticas tais como movimentos sociais, ONGs internacionais, igrejas, corporações médicas e o próprio mercado), diversificando as pautas (indo além da gravidez e controle populacional para a pletora de elementos que condicionam a vida doméstica e familiar) e chegando cada vez mais perto das práticas e subjetividades corporificadas tão bem desenhadas por estudos etnográficos. Lembremos que a antropologia da reprodução já tinha estabelecido o eixo político do tema e já tinha ressaltado as inescapáveis desigualdades produzidas na interação das múltiplas agências nos processos reprodutivos. Agora, no seu artigo dirigido especificamente para estudos na América Latina, Morgan e Roberts acrescentam a insistência nos "regimes morais" que, por lógicas globais perpassando as estratégias nacionais de intervenção, exercem uma influência normalizadora sobre as práticas de reprodução, os comportamentos sexuais e as relações de gênero.

O pensamento de Foucault, com destaque aos regimes de verdade que subjazem às diferentes formas de biopoder, é um elemento central nessa guinada. Contudo, ao insistirem na importância central dos significados e valores que afloram no curso da vida, Morgan e Roberts apelam às perspectivas de Fassin (2009) sobre as "políticas da vida". Nessa proposta, sublinha-se o fato de que valores diferentes acompanham vidas diferentes, e, portanto, os modos de subjetivização talvez não sejam os mesmos em cima e em baixo da hierarquia social. Trata-se de uma análise que, sem perder de vista as influências mais abrangentes, reflete as preocupações do olhar etnográfico com particularidades "locais", subjetividades individuais e compreensões coladas às práticas das rotinas cotidianas (por exemplo, de cuidado). Emerge assim a importância de o pesquisador atentar para as formas situadas de raciocínio moral, operando através de uma série de configurações heterogêneas, evocadas e retrabalhadas em situações problemáticas por pessoas em busca de um norte para seus modos de agir.

O destaque analítico dado aos "sentidos e valores" que orienta a análise da governança reprodutiva se consolida numa conjuntura política global altamente conturbada em que certas conquistas parecem estar sendo desfeitas. Nos Estados Unidos, por exemplo, o avanço de um eleitorado com forte viés religioso e conservador já levou diversos estados a passar legislação que praticamente anula o direito ao aborto consagrado pela Corte Suprema décadas 
atrás. No atual cenário polarizado, o direito da mulher a terminar sua gravidez é cancelado pelo direito do feto a nascer; a ênfase discursiva é deslocada da liberdade reprodutiva de uma pessoa viva para o futuro imaginado de um humano em potencial (Krause; De Zordo, 2012). Na América Latina, onde houve só recentemente, e em poucos países, a descriminalização do aborto, vemos como a legislação progressista não é em si garantia de novos direitos. Mesmo em países como o Uruguai, onde à força de duras lutas foi possível derrubar as proibições legais, médicos ainda aproveitam brechas na legislação para, à base da convicção íntima, exercer seu direito a recusar realizar uma interrupção de gravidez (Rostagnol, 2015, 2016). No mundo inteiro, assaltos orquestrados contra uma suposta "ideologia de gênero", apoiados por setores evangélicos e alas conservadoras da Igreja Católica, renovam campanhas morais de grande potência, enaltecendo a família heterossexual tradicional e condenando qualquer sexualidade não atrelada à reprodução (Cornejo-Valle; Pichardo, 2017).

No cenário contemporâneo, a própria linguagem de direitos se mostra vulnerável a ressignificações que podem implicar um redirecionamento radical de sentidos. Tanto Sanabria (2010) como Krause e De Zordo (2012), ao considerar programas de planejamento familiar no Brasil dirigidos especificamente para mulheres de baixa renda, apontam para esse tipo de paradoxo. Por um lado, as diferentes formas de contracepção são sistematicamente pautadas como "direito" de cidadã, permitindo maior autonomia feminina. Por outro lado, são apresentadas como dever moral, com o entendimento que a não adesão só pode ser fruto de ignorância ou falta moral da mulher que, assim, coloca em perigo não só o bem-estar da família, mas o desenvolvimento da nação. Dessa maneira, a noção de "autonomia" feminina reforça sutilmente políticas neoeugênicas objetivando coibir a fertilidade de pessoas de certa classe e cor (Brandão e Cabral, neste número). Outra situação paradoxal vem à tona nos casos de gestação por substituição, quando os direitos da criança são evocados para passar por cima de proteções básicas das mulheres, "barrigas de aluguel", contratadas para gestá-las (Van Wichelen, neste número). Ou, como vimos no episódio que abre este texto, o princípio do "melhor interesse da criança" é acionado para retirar crianças de suas famílias em situação de vulnerabilidade social. Reconhecendo que a compreensão desses aparentes paradoxos requer um olhar que vai além das leis, das políticas explícitas e das instituições estatais, pesquisadores voltam suas lentes analíticas para a gênese e mecanismos de fomento 
dos valores e sentidos que subjazem às diferentes tomadas de decisão sobre as práticas reprodutivas nas suas diversas escalas.

Nessa conjuntura, o convite feito por Laura Briggs (2017) para pensarmos todas as políticas enquanto políticas reprodutivas vem a calhar. Inspira-nos a reconsiderar o papel de um conjunto de práticas/ações que por um longo período foram tomadas como fundamentalmente pertencentes à esfera privada, relegadas à invisibilidade, e trazê-las à luz de questões mais amplas. Assim, adentramos não só nas temáticas mais comumente associadas a essa, tais como reprodução assistida, aborto, gravidez, contraceptivos, mas também os componentes críticos do trabalho reprodutivo em pautas como bem-estar social, imigração, cuidados infantis, dinâmicas familiares, casamento gay, direitos civis, assistência social e pensões, etc. Trata-se, como insiste a autora, de um trabalho real/concreto produto e produtor da política. Nos últimos tempos, o trabalho reprodutivo tem se tornado mais importante do que nunca, sobretudo em função da privatização das tarefas de cuidado, e por isso a exclusão dessa pauta dos debates políticos e econômicos gerais tem se tornado cada vez mais intolerável. Os artigos reunidos no presente número ilustram bem a proposta de Briggs. Não obstante uma grande diversidade de temas - práticas ginecológicas, violência obstétrica, parto e amamentação cruzada, experiências de maternidade e maternagem, adoção e acolhimento familiar, reprodução assistida, gestação por substituição e políticas de reprodução - todos os trabalhos, de maneira mais ou menos direta, são atravessados pelo diálogo entre trabalho reprodutivo e política.

\section{Especificidades do Norte global}

Na sua introdução ao volume em que o artigo de Morgan e Roberts foi publicado, Krause e De Zordo (2012) recorrem à ideia de biopolítica para descrever as racionalidades de reprodução através da divisa Norte-Sul. Boa parte da reflexão destas autoras é dedicada a situar problemas de governo numa conjuntura de grandes mudanças demográficas, incluindo, em algumas partes do mundo, uma baixa dramática de natalidade. As autoras dos diferentes artigos - sobre Polônia, Itália, Paquistão, e Brasil - elaboram densas descrições de seus respectivos contextos, ressaltando especificidades de comportamentos reprodutivos. 
Porém, o saldo teórico da justaposição de casos é dirigido ao que estes têm em comum. Em alguns lugares, as flutuações nos padrões de fertilidade podem ter ressignificado programas de planejamento familiar, usando inclusive uma linguagem dos direitos sexuais e da saúde da mulher, mas a globalização neoliberal tem provocado dilemas que "se espelham". Do Norte global ao Sul, vigilância e disciplina, assim como perspectivas neomalthusianas, ainda fazem parte das políticas de fertilidade (Krause; De Zordo, 2012). Apesar de apreciar esses argumentos, ao organizar o presente número, nos colocamos constantemente a pergunta: como que o posicionamento (nacional e geográfico) do observador cria relações diferentes com um termo tal como "governança reprodutiva"?

No hemisfério norte, vindo se somar aos assuntos clássicos da antropologia da reprodução, testemunhamos desde o inicio dos anos 2000 uma grande proliferação de estudos sobre, além da adoção transnacional, as intervenções médicas de reprodução assistida (ver, por exemplo, Birenbaum-Carmeli; Inhorn, 2009; Sargent; Browner, 2011). Nós imaginávamos neste número de Horizontes Antropológicos uma proporção algo semelhante entre as submissões que receberíamos, mas essa expectativa não se realizou. Em compensação, vieram muitas pesquisas empíricas sobre os aparatos e moralidades que perpassam a relação entre pais, mães e filhos. Esse desvio do roteiro imaginado nos levou a refletir sobre possíveis fatores contextuais na explicação da ênfase diversa de preocupações.

Pensando especificidades do Norte global, olhemos em primeiro lugar para a grande atenção atribuída às mudanças demográficas das últimas décadas que parecem ter transformado a paisagem da vida familiar. É compreensível que, diante da queda dramática de fertilidade ocorrendo nos Estados Unidos e especialmente na Europa ocidental, tenha prosperado uma nova linha de pesquisa sobre as dificuldades dos cidadãos comuns (em geral, das camadas médias) em conceber um filho. Assim, a preocupação de analistas passou a ser menos com as insuficiências dos programas de planejamento familiar (já amplamente difundidos), e mais com a crescente demanda de pessoas frustradas por não conseguirem formar uma família.

Embora a ausência involuntária de filhos tenha se enunciado como problema em muitos países euro-americanos já nos anos 1990, a experiência espanhola se destaca pela maneira rápida e intensa como esse problema surgiu (Alvarez; Marre, 2021). Em 1978, a taxa de fecundidade era de 2,77 filhos por mulher, a mais 
alta da Europa. Até 1993, tinha caído para 1,3 - uma das mais baixas do mundo e bem abaixo da reposição demográfica. Se, logo depois da Segunda Guerra Mundial, calculava-se que apenas $10 \%$ das espanholas nunca teriam filhos, passados 30 anos, essa proporção já era quatro vezes maior. Parte desse aumento é atribuída à tendência de mulheres a entrar no mercado de trabalho em número cada vez maior. Muitas delas acabam se dedicando a suas carreiras, adiando a maternidade para um momento quando as chances de engravidar são menores. Mas existem, como nos lembra Briggs (2017), outras influências das políticas neoliberais que passam a restringir as aspirações à vida familiar. A redução do valor real de salários fez com que ambos os membros do casal tivessem que se engajar na força de trabalho, inclusive com uma carga horária maior do que em gerações anteriores. Simultaneamente, com as restrições orçamentárias para serviços públicos de apoio, a responsabilidade pelos cuidados de pessoas dependentes passou a recair cada vez mais sobre as famílias nucleares (principalmente sobre as mulheres). Restrito ao setor comercial, o custo de um eventual auxílio por ajudantes pagos ficou proibitivo para boa parte dos jovens casais. Assim, até ter a estabilidade financeira para equilibrar as diversas demandas (domésticas, maternas, profissionais) às quais deviam atender, muitas mulheres já teriam atingido uma idade que tornaria a procriação "natural" difícil.

$\mathrm{O}$ alto custo dos diferentes processos "assistidos" de ter filhos - quer seja através da adoção ou da intervenção médica- introduz uma segunda particularidade que distingue o hemisfério norte do sul. Enquanto as políticas neoliberais de austeridade faziam estragos no mundo inteiro, boa parte dos cidadãos da Europa ocidental e a América do Norte - seja pelo emprego, seja pelas subvenções estatais - ainda gozavam de condições que lhes permitiam participar dos variados mercados de consumo. É nesse contexto que pesquisadores chamam atenção para a maneira como as relações íntimas, e também os demais elementos do trabalho reprodutivo tradicionalmente associados à esfera doméstica, se tornaram objeto de comodificação (Constable, 2009). Práticas tais como adoção infantil e maternidade assistida tomam seu lugar, ao lado de outros serviços reprodutivos, para se transformar em produtos mercadológicos, envolvendo pesados investimentos e lucros financeiros de uma classe média vultosa.

Lembremos que, num primeiro momento, mulheres tendo dificuldade para engravidar procuravam resolver seu problema, tal como em gerações anteriores, pela adoção de um bebê. Entretanto, por diversas razões, a oferta "local" de 
crianças disponíveis para adoção minguou, não suprimindo mais a demanda. A partir dos anos 1970, diminuiu o número de gravidezes imprevistas. Além do desenvolvimento de contraceptivos de uso acessível e a baixo custo, a interrupção voluntária da gravidez passou a ser uma opção nos Estados Unidos e em um número crescente de países da Europa. E, graças a uma moralidade sexual mais liberal e à ampliação de subvenções públicas, mesmo os nascimentos não programados passaram a ser aceitos com maior facilidade. Diante da carência de recém-nascidos disponíveis, pais pretendentes - por exemplo, nos Estados Unidos - podiam voltar suas esperanças para os serviços públicos de acolhimento. Passavam assim a aceitar uma criança (não mais um recém-nascido) retirada de sua família inevitavelmente pobre e pertencendo a uma minoria étnica discriminada, com ou sem o consentimento dos pais. Contudo, em pouco tempo, surgiram reações organizadas pelos movimentos negro, indígena e outras minorias protestando contra essas adoções "transraciais" (Modell, 1998; Roberts, 2002). É diante desse impasse, deparando-se com uma escassez de crianças adotáveis no seu próprio país, que pessoas sofrendo da "ausência involuntária de prole" passaram a buscar a criança desejada (de preferência, bebê, de pele clara e em boa saúde), a grande custo financeiro, nas regiões mais pobres da América Latina, da Ásia e eventualmente da África (Ballard et al., 2015; Marre; Briggs, 2009). As desigualdades que separavam as populações em fornecedoras e recebedoras de crianças adotadas se estenderam assim para incluir regiões do outro lado do globo.

No início da onda de adoções transnacionais, existiam poucas regulações sobre o processo. E mesmo quando surgiu, em 1993, a Convenção de Haia sobre a adoção transnacional, a legislação internacional parecia servir antes para azeitar do que para estancar os fluxos (Van Wichelen, 2019). Porém, aos poucos, os países mais visados (Brasil, Guatemala, China) passaram a impor restrições à adoção internacional, obrigando os pretendentes estrangeiros a procurar novos territórios. As rotas da adoção transnacional já tinham mudado várias vezes de curso antes de 2004, quando - com as portas fechadas pela grande maioria dos países do Sul - o número de transações entrou em declínio definitivo (Selman, 2012).

Esse declínio se deve pelo menos em parte a uma outra característica que cabe destacar sobre o cenário reprodutivo dos países do Norte global: a grande popularidade das novas tecnologias reprodutivas que surgiram simultaneamente à expansão da adoção transnacional. Essa popularidade veio acompanhada da 
expansão de oportunidades de viagem. Conforme a grande variabilidade de condições de acesso, custos, regulamentação legal e qualidade de serviços, os "consumidores" dessas tecnologias passaram a se deslocar entre países e mesmo entre os continentes, forjando rotas sempre renovadas de "reproturismo" (Birenbaum-Carmeli, Inhorn, 2009). Na Espanha, por exemplo, junto com a diminuição da adoção transnacional (no início dos anos 2010), o número de ciclos de reprodução medicamente assistida passa por um aumento astronômico. Com acesso praticamente aberto a gametas femininos de terceiras, os tratamentos dão resultados positivos, inspirando um grande influxo de viajantes de países limítrofes e mesmo mais distantes. Desde 2016, o país consta como campeão europeu em número de procedimentos de reprodução assistida (Marre; San Román; Guerra, 2018). Em contrapartida, por causa de restrições nacionais, algumas pessoas principalmente casais de homens - são obrigadas a viajar para o exterior (para os Estados Unidos, Ucrânia, Geórgia e México) em busca de mulheres que aceitarão colaborar num procedimento de gestação por substituição.

As observações de Duchesne (neste número) sobre mulheres africanas nas clínicas parisienses de fertilidade nos trazem uma ilustração viva dos deslocamentos transnacionais para fins reprodutivos. A etnógrafa trava contatos tanto com imigrantes já residindo na França que conseguem aproveitar os serviços de saúde pública quanto com as viajantes recém-chegadas no país com o propósito de pagar um tratamento em alguma clínica privada. Por sua descrição, se torna evidente como - naquele contexto - a conjunção de tecnologias (de telefones celulares, rotas aéreas e técnicas de fecundação in vitro) fomentam comportamentos reprodutivos que evocam novas autoridades (médicas e legais) ao mesmo tempo que preservam muitos dos controles "tradicionais", regidos por estereótipos de gênero e da família estendida.

Os deslocamentos transnacionais colocam em destaque, como nunca antes, a influência de normas legais na configuração de comportamentos familiares. Definições legais sobre as práticas de pessoas gays e lésbicas - em relação ao matrimônio, à adoção e às novas tecnologias reprodutivas - determinam formas familiares diversas. Na França, por exemplo, diante de leis que restringem a possibilidade de certas intervenções médicas, arranjos de parentalidade compartilhada entre casais gays e lésbicos são bastante comuns. Trata-se de homens e mulheres que, diante da dificuldade legal em conseguir certos tratamentos biomédicos, entram em acordos informais de reciprocidade entre 
doadores de gametas e útero (Tarnovski, 2013). O reconhecimento legal dos filhos engendrados através desses acordos envolve ainda novos desafios, especialmente numa conjuntura de frequente migração transnacional. Por exemplo, certa belga conseguiu no seu próprio país ser reconhecida mãe legal da criança nascida de sua parceira. Contudo, quando o casal se mudou para a Itália, onde não se reconhece nem o matrimônio, nem o direito à adoção de pessoas gays e lésbicas, o status legal desta mãe virou pó (Sarcinelli, 2018).

Os problemas que podem surgir em decorrência da incompatibilidade de leis entre um país e outro ficam bem exemplificados no artigo de Van Wichelen (neste número). Examinando casos julgados pela Justiça na Austrália de casais gays que contrataram mulheres na Índia para gestar seus filhos, a autora explora as "biolegalidades" produzidas pelas novas tecnologias em interação com corpos, desejos familiares, e atitudes morais. Ficam aparentes, na sua análise, os dilemas enfrentados por juízes à procura de critérios para avaliar casos que, por envolverem acordos comerciais (proibidos na Austrália, permitidos na Índia), são associados ao "tráfico" de bebês e partes do corpo humano. Para enfrentar as inúmeras incertezas morais que imperam em casos de gestação por substituição, juízes apelam ora a conhecimentos ligados à adoção (sem nenhuma intervenção médica), ora a conhecimentos biogenéticos (que averiguam conexões genéticas). Paradoxalmente, chegam a evocar princípios dos direitos humanos (sobre os direitos da criança) para estabelecer o vínculo legal entre pai e filho, apesar de a criança ter sido engendrada por um acordo comercial criminalizado pela lei nacional. Chamando atenção às inúmeras ambiguidades criadas no desencontro das diferentes camadas de lei - estadual, nacional e internacional, - a análise de Van Wichelen sublinha a necessidade de uma reflexão coordenada a nível internacional para encarar esses processos transnacionais de reprodução estratificada.

Dadas as novidades desse contexto, é compreensível que, na Europa e na América do Norte, pesquisadoras engajadas no campo da antropologia da reprodução tenham concentrado suas energias na análise dos custos, fluxos geográficos e desigualdades implicados nas adoções transnacionais e nas práticas medicamente assistidas de reprodução (Courduriès; Herbrand, 2014; Desy; Marre, 2021; Marre; Briggs, 2009; Marre; San Román; Guerra, 2018). A questão é por que não encontramos uma semelhante concentração nesses temas entre pesquisadores na América Latina? 


\section{América Latina: preocupações particulares de governança reprodutiva}

Testemunhamos, na América Latina, uma longa e vigorosa linha de pesquisa feminista, a partir de perspectivas críticas e foucaultianas, sobre "racionalidades populacionais" voltadas para o planejamento familiar e o aborto. Não por acaso, o único artigo sobre a América Latina no volume de Ginsburg e Rapp $(1995)^{3}$ focou as controvérsias girando em torno de um certo contraceptivo subcutâneo (Norplant), sendo testado no Brasil dos anos 1980 (Barroso; Correa, 1995). Por um lado, havia as organizações internacionais aderindo à tese "populacionista", conforme a qual a sobrepopulação é a causa principal do subdesenvolvimento. Por outro lado, havia setores do governo brasileiro que abraçavam perspectivas nacionalistas, alegando que, para enfrentar as forças do imperialismo, era preciso uma população grande. Perpassando debates sobre as vantagens e desvantagens do crescimento populacional, surgiam considerações sobre o direito das mulheres a exercer controle sobre seus corpos e sua fertilidade. Em certos casos, existiam efeitos colaterais (menstruação excessiva, libido diminuída) que as próprias usuárias podiam considerar mais graves do que uma gravidez não planejada. Mas o fato de a tecnologia exigir intervenção médica tanto para retirar quanto para colocar o contraceptivo levantava dúvidas quanto ao poder da mulher de desistir do tratamento. Afinal, nesse emaranhado de engajamentos, incluindo os interesses financeiros da indústria farmacêutica, as autoras apontaram para o forte viés dos gestores públicos a favor do progresso científico - o que complicava a garantia de um procedimento ético nos ensaios clínicos.

Trazendo essa profícua linha de investigação para o cenário atual, Brandão e Cabral (neste número) analisam uma política no sistema público da cidade de São Paulo visando desestimular a fertilidade reprodutora de mulheres jovens e pobres, marcadas por indicadores de raça, etnia e classe. Trabalhando a partir de um programa de long-acting reversible contraceptives (LARC), mostram o

3 O seminário apoiado pela Wenner-Gren Foundation for Anthropological Research realizado em Teresópolis (nas montanhas perto de Rio de Janeiro) que deu origem a esse volume contou com a participação de uma demógrafa cubana, mas, entre os 20 capítulos do livro, o de Barroso e Correa é o único de autores da América Latina. 
quanto, não obstante 30 anos de críticas ao populacionismo e debates em torno do empoderamento das mulheres, a lógica de "coerção contraceptiva" reaparece com seus velhos tropos neoeugenistas. Ao oferecer essa "nova" tecnologia contraceptiva curiosamente aparentada ao Norplant dos anos 1980, os gestores públicos apelam para uma linguagem de proteção à saúde, direitos reprodutivos e autonomia reprodutiva. Entretanto, na prática, ao promover o acesso à tecnologia principalmente (se não exclusivamente) a mulheres socialmente excluídas, sublinhando as vantagens econômicas para os cofres públicos, repetem políticas estratificadas e racializadas, reificando estereótipos que supõem a necessidade de tutelar as práticas reprodutivas dos setores vulneráveis da população.

Tal como seus colegas no Norte global, antropólogas feministas latino-americanas olhando para a reprodução diversificaram os temas de estudo para além da planificação familiar. Mas particulares fatores contextuais, sem dúvida, tiveram um papel na criação de ramificações um tanto distintas. Consideremos, primeiro, a questão demográfica. Na América Latina, apesar de ter acontecido uma queda igualmente dramática nas taxas de natalidade, essa situação não chegou ao ponto de ameaçar a reposição demográfica. Não se constituiu em problema a ser discutido, por exemplo, em debates públicos. Embora o aborto tenha sido descriminalizado recentemente em um pequeno número de países (Viera Cherro, neste número), o procedimento continua de difícil acesso à grande maioria de mulheres. Assim, entre o nascimento de filhos não programados e as condições miseráveis nas quais vive boa parte da população, o imaginário público continua a associar as dificuldades que assolam a sociedade (pobreza, criminalidade, etc.) a "famílias desestruturadas". Essas "fábricas de elementos desajustados" (nas palavras do atual vice-presidente do Brasil) seriam a consequência se não do excesso de filhos, pelo menos da socialização problemática deles (ver Efrem Filho e Mello, neste número). Destarte, na visão de boa parte dos dirigentes políticos, o problema não seria o número (de mais ou de menos) de crianças nascendo, mas a distribuição inadequada delas.

Quanto à adoção, a ausência involuntária de filhos na América Latina vinha sido tradicionalmente vista como um problema privado de um número reduzido de pessoas que podiam resolver a situação pela adoção informal, sem a interferência do poder público (Leinaweaver; Seligmann, 2009; Rinaldi, Coitinho Filho, Souza e Souza). A adoção passou a ser uma pauta importante da agenda pública só no final do século passado, justamente por causa 
dos estrangeiros que vinham buscar filhos adotivos nessa região do mundo. A América Latina tinha se conectado aos circuitos de adoção transnacional como fornecedora de crianças para famílias na Europa e América do Norte (Cardarello, 2012). Contudo, à medida que as estruturas de governo foram sendo aprimoradas na era da reabertura democrática, os governos nacionais tendiam a concentrar a administração da adoção no Judiciário para garantir o prevalecimento do "interesse superior da criança”. O importante era prevenir abusos que tinham ocorrido no passado, tal como a apropriação criminosa de crianças durante a ditadura argentina (Villalta, 2012) e o tráfico internacional de bebês para a adoção. Assim, no Brasil, por exemplo, vedava-se a autorização de agências privadas ou quaisquer outros intermediários que não fossem do poder público. Os controles crescentes praticamente deram fim a adoções por estrangeiros (que caíram de mais de 2.000 em 1990 para 67 em 2018), e colocaram limites aos trâmites da adoção doméstica.

Invertendo visões anteriores, emergiu a narrativa de que faltavam crianças disponíveis à adoção no país - pelo menos crianças na primeira infância e em boa saúde, tal como a maioria de pretendentes desejava. Desde 2008, quando as estatísticas oficiais passaram a ser divulgadas na mídia, os números anunciam inevitavelmente cinco a seis pretendentes para cada jovem disponível. Apesar de existir um aparato institucional (profissionais, cadastros, etc.) para regular o encontro entre adotantes e adotados, em certas regiões, os magistrados encarregados da adoção continuam ligados a redes filantrópicas e grupos associativos de pais adotivos, muitos sob forte inspiração religiosa. Longe de terem recursos para buscar um filho adotivo no exterior, pretendentes à paternidade adotiva acabam se enredando nessas redes locais. E é nessa conjuntura de discursos sobre direitos da criança, misturados a moralidades filantrópicas e humanitárias, que a maioria de pesquisadores da adoção tem concentrado suas energias (Finamori, Silva, 2019; Rinaldi, 2019; Uziel, 2007).

As novas tecnologias reprodutivas, por sua vez, já chamavam interesse na América Latina desde os anos 1980, quando nasceram os primeiros bebês por esse meio, mas só chegaram a criar maior impacto em torno da virada do milênio. Surgiu, então, uma pletora de estudos nos laboratórios e nas clínicas médicas sobre as consequências dessa nova fase da biomedicalização da reprodução (Grossi; Porto; Tamanini, 2003; Luna, 2007; Ramirez-Galvez, 2009; Straw et al., 2016; Tamanini, 2015). A produção dava destaque em particular à maneira 
como o uso de gametas doados por terceiras abria possibilidades não só para solteiras, mas para casais gays e lésbicos. Na ausência de leis sobre essa prática médica, sugiram orientações emitidas por corporações médicas (tal como o Conselho Federal de Medicina no Brasil) estabelecendo as normas aceitáveis de atuação profissional. Com o avanço dos direitos sexuais das comunidades LGBTT - o reconhecimento do matrimônio entre parceiros do mesmo sexo e seu direito de adotar crianças -, diminuem na maioria de países da região as restrições que dificultavam a reprodução por casais homossexuais (Straw et al., 2016). Contudo, por causa das relações nem sempre claras entre o governo, a ciência médica e o os lucros proporcionados pelas tecnologias de procriação medicamente assistidas, permanecem preocupações sobre os possíveis riscos das inovações tecnológicas para a saúde dos vários atores envolvidos.

Viera Cherro (neste número), na sua discussão sobre as novas tecnologias reprodutivas no Uruguai, retoma a complexa relação entre elementos encarnados (biológicos) dos processos reprodutivos, gênero e a bioeconomia global, acrescentando a questão fundamental da religião. Expõe, por um lado, o dogma altamente conservador do Vaticano veiculado por especialistas católicos da bioética e de lideranças nacionais do clero. Foi sob a influência dessa doutrina que a primeira lei uruguaia sobre a reprodução medicamente assistida (2003) ditou parâmetros estreitos de ação, restringindo intervenções a casais heterossexuais, sem possibilidade de doação de óvulos por terceiras. Por outro lado, ao destacar como foi um católico praticante que dez anos depois patrocinou uma lei muito mais progressista, a autora embaralha qualquer associação mecânica entre dogma, crença e prática. Ao aprender que, já desde o início do século, três quartos das intervenções envolvendo doação de esperma eram realizadas por casais lésbicos, o leitor acaba por se convencer de que a nova lei simplesmente legalizou práticas que já vinham ocorrendo de forma rotineira. Numa evidente cumplicidade solidária entre profissionais e pacientes, as mulheres com dinheiro suficiente conseguiam pagar um procedimento, independentemente da orientação sexual (ou religião).

A introdução do aspecto financeiro do tratamento, com a possibilidade de comercialização de serviços e acúmulo de lucros, abre a discussão para uma tensão frequentemente silenciada nos debates éticos. Procedimentos tais como doação de óvulos e criopreservação de embriões não só colocam em destaque o biovalor dos materiais, como também implicam um "trabalho 
clínico" (Cooper; Waldby, 2014) de vulto da parte de doadoras cujos corpos são submetidos a tratamentos químicos violentos. Críticas feministas, entre outras, chamam atenção para o fato de que enquanto as clínicas cobram altas taxas para o trabalho especializado dos profissionais, as mulheres que doam material biológico não recebem mais do que compensações simbólicas. Ou são mulheres que doam os óvulos "excedentes" para custear seu próprio tratamento, ou são mulheres de origem relativamente modesta que fazem uma doação solidária mediante um "lucro cessante". Mais preocupante ainda, na ausência de qualquer regulamentação sobre o número de vezes que uma mulher pode doar seus óvulos ou de protocolos para controlar a dosagem de estimulantes usados no tratamento, não existem limites à exploração do "trabalho clínico" dessas doadoras. Viera Cherro conclui comentando como, apesar de ambos apontarem possíveis objeções aos novos procedimentos biotécnicos de procriação, o dogma católico e a crítica feminista divergem radicalmente quanto aos motivos. Enquanto teólogos, preocupados com a desumanização, querem preservar uma humanidade abstrata, as feministas, fitando as grandes desigualdades implicadas na reprodução estratificada, querem prevenir a exploração do trabalho corporal de mulheres concretas vivendo em circunstâncias de vulnerabilidade.

Viera Cherro levanta questões sumamente relevantes a partir de sua pesquisa em clínicas no Uruguai. Contudo, resta a questão: na América Latina, até que ponto as novas formas medicamente assistidas de procriação estão afetando a vida da grande proporção da população vivendo na ou à beira da pobreza, aquelas pessoas que mal têm recursos para acessar os elementos necessários da saúde básica? No Brasil, lembremos que 95\% da demanda por esses tratamentos são atendidos pela medicina privada. Existem alguns hospitais públicos trabalhando nessa área, mas as listas de espera são longas e as necessárias medicações (pagas em geral pelos pacientes), caras. Mais importante: nenhum desses serviços oferece tratamentos de alta complexidade - 0 que resulta em taxas muito modestas de êxito. Podemos supor que a conclusão de uma observadora sobre o caso brasileiro serve para boa parte da América Latina: "Até o momento, a principal exclusão do acesso à FIV é de base econômica: o custo dos bebês de proveta os torna inacessíveis a uma enorme parcela da população interessada" (Corrêa; Loyola, 2015, p. 763; ver também Nascimento, 2020). Nos últimos dez anos, houve esforços da parte de militantes por 
direitos reprodutivos de democratizar o acesso às tecnologias reprodutivas ver por exemplo a recente legislação na Argentina e no Uruguai (Straw et al., 2016; Viera Cherro, neste número). Resta a ver se, num quadro de redução de gastos públicos, será possível alcançar resultados práticos em qualquer escala significativa.

Quanto ao "reproturismo", existem estudos interessantes sobre mulheres abastadas que procuram gametas doados de clínicas no exterior, de preferência nos países nórdicos (Vitule; Fachin; Couto, 2016); também despontam alguns casos de pessoas tentando legalizar a filiação de uma criança nascida no exterior por uma gestação sub-rogada (tecnologia quase impossível de ser realizada localmente). Entretanto, em geral, fora a elite cosmopolita, até as chamadas "camadas médias" têm dificuldade de juntar dinheiro suficiente para uma viagem ao exterior, que dirá pagar um tratamento de maternidade assistida. Nesse quadro, compreende-se que muitos pesquisadores virem suas atenções - antes do que para os procedimentos em si - para as promessas infladas das intervenções médicas e os vieses questionáveis das suas infraestruturas comerciais e científicas (Allebrandt, 2021; Freitas, 2021; Nascimento, 2020; Ramirez-Galvez, 2009; Viera Cherro, 2019).

Ao todo, esse quadro ajuda a entender por que, entre os analistas voltados para os problemas de governança reprodutiva na América Latina, a desigualdade que inquieta diz respeito não às relações entre os países e, sim, às relações de classe, raça e etnia dentro de suas fronteiras nacionais. Os processos de reprodução estratificada operam a partir do lugar inferior e discriminado que ocupam mulheres perto de casa - aquelas cujos filhos serão transformados contra a vontade delas em "disponíveis para a adoção" e aquelas que "doarão" seus gametas para facilitar a formação de uma família por mulheres mais abastadas.

Será por acaso que a noção de governança reprodutiva, com sua ênfase nos regimes morais, tenha sido originalmente elaborada em relação a uma região fora do eixo Europa-Estados Unidos? Cabe notar que, naquele volume de 2012 em que se anuncia a ideia de governança reprodutiva, o único trabalho que não fala de racionalidades demográficas (planejamento familiar ou problemas de fertilidade) é o de Cardarello sobre o Brasil. A atenção desta autora é dirigida às moralidades que julgam certas mulheres indignas de serem mães. Seguindo o protesto de famílias cujos filhos foram dados em adoção (alguns adotados no exterior) sem seu consentimento, mostra como as justificações invocadas 
por membros do Judiciário para anular os direitos destas famílias refletem estereótipos arraigados de classe e raça. Sugerimos que a incorporação desse episódio no debate sobre governança reprodutiva - um episódio que se remete a desigualdades dentro da nação e que diz respeito não à concepção e ao parto, mas ao disciplinamento dos comportamentos parentais - sublinha as preocupações de pesquisadores do Sul global, além de prenunciar uma guinada na arena de debate acadêmico.

\section{Moralidades de maternidade e gênero}

Até o fim do século passado, já era evidente para a maioria dos cientistas sociais que os mecanismos de governo diziam respeito a muito mais do que os instrumentos mais visíveis do poder (legislação, tribunais, polícia). Para propiciar de forma efetiva determinadas condutas, era preciso incluir a colaboração de uma variedade de aparatos profissionais e administrativos. Esse conjunto de aparatos normalizadores requeria a validação por saberes científicos. Assim, apelando para a natureza técnica antes do que política das normas que promoviam, um novo exército de "pequenos juízes", ajudaria a moldar subjetividades e dirigir comportamentos para determinados fins (Rose; Valverde, 1998). Por exemplo, os profissionais da pediatria e outros especialistas da mulher e da criança não só definiam os modos adequados do desenvolvimento e educação infantis, como também adquiriam a suposta capacidade de prever a saúde futura da população. São essas definições e essas atribuições - com seu poder de estabilizar e disseminar padrões de normalidade no tocante a assuntos como corpo, gênero, sexualidade e família - que inspiraram uma grande escola de analistas a investigar as implicações morais da própria ciência médica.

É compreensível que, ao se debruçarem sobre assuntos da biomedicina, um importante contingente de antropólogas da reprodução chama atenção para problemas ligados ao acesso desigual ou práticas discriminatórias - quando, por exemplo, constata-se que mulheres negras, indígenas ou simplesmente pobres são sujeitas a formas particulares de violência obstétrica na rede pública de atendimento (Castro, Savage, 2019; Sesia 2020). Surgem também preocupações mais do que relevantes quanto às insuficiências dos serviços básicos - quando, por exemplo, a política da "saúde integral da mulher" anunciada por gestores 
públicos não vem acompanhada de uma distribuição de tempo e recursos suficientes para que os médicos realizem os objetivos do programa (Mines Cuenya, neste número) ou quando as campanhas para a promoção de implantes contraceptivos não contemplam o acesso facilitado a serviços de atendimento para o controle dos efeitos colaterais (Brandão e Cabral, neste número).

Entretanto, para além dessas instâncias mais visíveis de discriminação, analistas têm dirigido seu olhar para problemáticas menos evidentes, observando de que maneira as moralidades de gênero são sutilmente construídas, transmitidas e eventualmente renegociadas nos gabinetes médicos. Não há dúvida que, via manuais, tratados e cursos de capacitação dos especialistas, as ideias veiculadas pelas ciências atravessam o globo com cada vez mais abrangência, difundindo perspectivas normativas sobre as relações mais íntimas da vida doméstica. Encontramos reflexos dessa linha de análise no trabalho de Mines Cuenya (neste número) que descreve amiúde como, na Argentina contemporânea, especialistas da "tocoginecologia", seguindo orientações que circulam globalmente entre a OMS e os ministérios de Saúde nacionais, reforçam determinadas visões de corpo e saúde da mulher, revolvendo sempre ao redor da função reprodutiva (cis)gênero. Trazendo aportes da antropologia da saúde assim como dos estudos feministas da ciência e tecnologia, o trabalho desta autora evoca uma já longa trajetória entre pesquisadores da América Latina, agregados pelo Centro Latino-Americano em Sexualidade e Direitos Humanos (CLAM). Nas várias revistas editadas nesse eixo (Physis; Sexualidad, Salud y Sociedad), se encontram reflexões de historiadores, psicólogos e cientistas sociais de toda a América Latina visando restituir uma história crítica do conhecimento médico enquanto força moralizadora do sexo e gênero (ver Rohden; Monteiro, 2019). Aprendemos nesses estudos que, mesmo se as imagens novecentistas de mulheres histéricas não circulam com a mesma força de antes, encontramos implícitas na medicina atual muitas das mesmas premissas. Seja nas discussões sobre hormônios "femininos" e "masculinos" (Rohden, 2019), ou nos debates sobre os efeitos cognitivos e neuronais da gestação e maternidade (Russo; Nucci, 2021), persiste a noção dos imperativos da natureza ditando conexões atemporais entre instinto, maternidade, corpo e comportamento femininos.

A dimensão moral dos julgamentos inscritos nas normas protocolares profissionais fica mais clara à medida que estes alcançam as fases pós-parto do processo reprodutivo. Analistas chamam atenção para certa ciência da 
primeira infância predicada na necessidade da presença materna em tempo integral, sob risco de o recém-nascido sofrer graves danos cerebrais (Fonseca, 2019; Gillies, Edwards, Horsley, 2017). Disseminados no mundo inteiro, programas de educação "alternativa" do Banco Mundial (além de organizações do setor privado) se baseiam nessa ciência para ensinar mães, inevitavelmente situadas em bairros e regiões pobres, os gestos e atividades da boa maternagem (Faircloth, 2013; Fonseca, 2012). No clima de racionalidade econômica neoliberal, esses programas de intervenção a domicílio fazem eminente sentido. Por um processo que custa aos cofres públicos bem menos do que uma creche pública ou pré-escola, a mulher deve se tornar gerente autodisciplinada do lar, para então produzir uma nova geração de pessoas autossuficientes, bem adaptadas às necessidades projetadas da futura economia de mercado. As fragilidades dessa racionalidade política se revelam nas múltiplas observações empíricas (Macvarish, 2016).

Kunin (neste número) descreve o desenrolar de um desses programas para a educação parental numa área interiorana da Argentina. Dirigindo-se a grávidas e mães de crianças recém-nascidas, coordenadoras (incluindo uma doula adepta do parto humanizado), além de fornecer um espaço para as mulheres expressarem seus anseios, ensinam exercícios meditativos de relaxamento. Tais práticas seriam importantes não só para permitir à mulher encontrar sua "vida interior", mas também para evitar que o estresse afete negativamente seu feto ou recém-nascido. Através da sensibilização das mulheres-mães, acionam-se noções específicas de corpo, pessoa e maternidade. Curiosamente, a autonomia e empoderamento da mulher parecem coincidir, nesse caso, com normas essencialistas sobre mãe-maternidade no seio de uma igualmente naturalizada família nuclear. Ensina-se que, para garantir sua autonomia e ter "opinião própria", a jovem mãe deve se informar, tomando distância dos "mitos" circulando entre as comadres da comunidade. É subentendido que, assim informada, essa "opinião própria" coincidirá com as noções divulgadas pelo próprio programa. Desembocará em práticas de maternidade intensiva, caracterizada pela relação estreita ("fusão" ou "simbiose") entre mãe e filho e eventualmente marido, com longo período de amamentação, e praticamente à exclusão dos demais membros da vizinhança e família extensa. De forma significativa, enquanto o curso é frequentado por mulheres vindas de fora da comunidade, as esposas dos trabalhadores agrícolas que moram no bairro parecem pouco preocupadas com o que 
elas veem como as experiências "naturais" de parto e maternidade, se contentando com a ajuda de sua rede tradicional de apoio feminino.

Dos saberes "técnicos" da ciência, chegamos às visões naturalizadas da moralidade familiar. Estaríamos no que Fassin (2009) denomina uma "economia moral" de normas, valores, sensibilidades e emoções em circulação ao redor de um tema: a família e reprodução. Os analistas, na sua maioria, concordam quanto à centralidade que a mulher ocupa nessa configuração no cenário contemporâneo neoliberal. Com o desinvestimento financeiro nos serviços públicos de apoio à vida doméstica, surge em substituição um pacote denso de orientações educativas e conselhos morais exortando as famílias (e, em particular, as mulheres-mães) a acudir (cada vez mais sozinhas) às necessidades das pessoas que dependem delas. Por um lado, essa conjuntura favorece um recrudescimento da idealização da figura sacrificada da mãe. Vide a homenagem feita pelo cineasta espanhol Pedro Almodóvar, em outubro de 2021, às mulheres que perderam seus filhos durante a guerra civil (1936-1939) e a ditadura de Franco (1939-1975): "Eu creio que os homens, por mais que nos esforcemos, jamais vamos entender a magnitude do que significa a maternidade, creio que não está em nossa genética entendê-lo" (tradução nossa). ${ }^{4}$

Por outro lado, o calcanhar de Aquiles dessa louvação aparece nos inúmeros programas sociais "maternalistas" que, contando sempre com a administração pela mulher-mãe, acrescentam mais um grau institucionalizado à sobrecarga de seu trabalho (Llobet; Milanich, 2014). Aparece, como extensão lógica dessa sobrecarga, uma acusação cada vez mais fácil contra a mulher que não está à altura das expectativas, isto é, que "falha" na sua responsabilidade de produzir filhos que serão cidadãos cumpridores da lei (Efrem Filho e Mello, neste número; Llobet e Villalta, neste número).

É a partir dessa economia que podemos melhor entender o episódio de Andrielli com o qual abrimos este texto. A mãe, já na maternidade hospitalar, é julgada inadequada não pelo seu comportamento atual (o bebê pode até ter aparência de ser muito bem cuidado), mas pela sua trajetória anterior (Gomes, 2017; Sarmento, 2020). O "risco" que a criança corre em algum momento futuro

4 Retomando o tema da maternidade, recorrente em sua filmografia, o cineasta proferiu esse discurso na apresentação de Madres paralelas, um filme que revela o drama das famílias cujos filhos foram fuzilados e enterrados em milhares de valas comuns, sem nunca serem identificados. 
é calculado a partir de uma hierarquia definida claramente por atributos morais de classe, justificando seu deslocamento para um lar mais abastado - primeiro, numa família acolhedora (como etapa transitória); depois, possivelmente, numa família adotiva (de forma definitiva e irreversível). Ficam escancarados os julgamentos morais que acompanham do início até o fim essa forma de reprodução estratificada, que, além de subestimarem o papel das desigualdades estruturais, viram um olho cego para dinâmicas locais de cuidado- tema que nos leva para considerações sobre a articulação profícua e potente entre trabalho reprodutivo e cuidado.

\section{Cuidado na governança}

Os textos reunidos neste número, assim como a história de Andrielli, em Florianópolis, revelam formas sofisticadas da administração contemporânea dos sujeitos/viventes, realizada, cada vez mais, através da reprodução (Memmi, 2003) ou mais especificamente do trabalho reprodutivo que envolve inevitavelmente elementos de cuidado. Recorremos à noção de cuidado ${ }^{5}$ para nos referir não apenas a uma atitude atenciosa ou uma atividade curativa altamente especializada, mas, antes de mais nada, a um conjunto de atividades materiais, técnicas e relacionais que objetiva oferecer uma resposta concreta às necessidades dos outros (Hirata; Molinier, 2012). "O cuidado não é somente um sentimento ou uma disposição, ele não é simplesmente um conjunto de ações. Trata-se de um conjunto complexo de práticas que se estendem desde os sentimentos mais íntimos como o 'pensamento maternal' até as ações extremamente largas, como a concepção dos sistemas públicos de educação" (Tronto, 2012, p. 265, tradução nossa). A noção se caracteriza por seu caráter multidimensional/transversal e polissêmico (Hirata; Debert, 2016; Hirata; Guimarães, 2012; Hirata, Molinier, 2012; Paperman; Laugier, 2011), bem como

5 Em que pese a dificuldade em traduzir a palavra care, em função da sua polissemia e dos riscos de redução de sentidos, optamos por manter o termo em português "cuidado", que nos parece guardar o sentido de care. Dessa forma, ao acionarmos a palavra "cuidado", desejamos destacar sua dimensão conceitual (Casanova; Brites, 2019) e também sinalizar que estamos mobilizando elementos/questões de uma trama teórico-conceitual diversa, que varia segundo os países, as correntes e as disciplinas. 
pela versatilidade das suas formas de exercício capaz de “[...] capturar múltiplas expressões, termos e sentidos acionados em diferentes contextos para articular um amplo leque de valores, afetos, compromissos, obrigações, práticas e aparatos administrativos [...]" (Lowenkron, 2016, p. 81).

Aproveitamos essa versatilidade para propor uma discussão, pouco elaborada nos trabalhos de governança reprodutiva, sobre o cuidado. Justamente pela maneira que abrange um amplo campo de ações e práticas, consideramos que o cuidado se relaciona intimamente, ora como figura, ora como fundo, com as tecnologias de governo. Nosso olhar se volta para além de uma relação diádica entre quem cuida e quem é cuidado, para o leque de agentes implicados nas múltiplas relações de cuidado e, portanto, para a dimensão política do cuidado (Bessin, 2012). Sugerimos que - por sua associação com formas de resistência e de agenciamentos múltiplos - o cuidado tem uma forte eficácia política que anda de par com seu potencial transformativo, suas lógicas de temporalização e as ambiguidades "agonísticas" que carrega. Tal como construímos esse diálogo, as autoras e os autores aqui reunidos nos apresentam experiências de cuidado cujos sentidos estão em permanente disputa, podendo a todo momento se alterar dependendo da perspectiva assumida por cada sujeito nas relações que estabelece.

Seguindo tal perspectiva, as experiências analisadas, no presente número, revelam as ambiguidades do "cuidado" (pelas fronteiras embaçadas e móveis entre proteção e controle, mercado e não mercado, entre âmbito profissional e doméstico, entre dominação e reciprocidade, técnicas e afetos, entre apego e repulsão e amor e ódio), sem, no entanto, cair na armadilha da dicotomização que essas oposições a princípio parecem sugerir (Paperman, 2011). Chamamos atenção em particular para o par proteção e controle/tutela que a noção de cuidado suscita. Entre estes se estabelece uma "relação agonística" que permite reforçar a ideia de que o cuidado opera tanto no registro da proteção (veiller sur) quanto no do controle/vigilância (surveiller); há, portanto, entre esses termos uma incitação permanente e produtiva (Bessin, 2011; Cruz Rifiotis; Rifiotis, 2019).

As ambiguidades do cuidado, e a "relação agonística" que se estabelece entre proteção e controle, aparecem fortemente no artigo de Llobet e Villalta (neste número), nas formas como se conjugam práticas estatais e dinâmicas familiares. Nos programas de acolhimento familiar, na Argentina, o cuidado das crianças se desenvolve segundo esquemas baseados em uma distribuição de gênero tradicional, a saber, são as mulheres que são encarregadas da 
maior parte das tarefas. Chama atenção o fato de estar expressamente proibido que essas mulheres recebam remuneração por tais tarefas. É justamente esse "caráter solidário" e "não remunerado" das tarefas de cuidado que é altamente valorizado no desenho do projeto e pelos próprios agentes. "Donde empiezan a darle dinero por cada niño, esto termina mal porque empieza a ser um trabajo", revela uma das profissionais do programa não governamental de acolhimento familiar observado pelas pesquisadoras. Do ponto de vista institucional e dos próprios agentes, cuidado e dinheiro não combinam. Para que o programa tenha um caráter de fato solidário o trabalho de cuidar precisa ser altruísta, precisa ser uma doação, há que se "fazer milagres" com poucos recursos e passar longe, portanto, de uma profissionalização.

Na base do programa está um certo "modelo familiar". Para funcionar, como o próprio nome diz, como se fossem uma família, as famílias acolhedoras devem ser orientadas por uma visão romântica em que assuntos de família não se misturam com assuntos de dinheiro ou finanças, pois estes seriam desprovidos de considerações, de sentimento e moralidades (Luna, 2007). Para imitar "la intimidad familiar sin alterar las relaciones de parentesco", seguindo orientações oficiais, as acolhedoras devem operar a dissociação entre as tarefas de cuidado e o "trabalho". Reatualizando a dualidade que tem sido longamente problematizada nos estudos sobre cuidado, "amor, afeto e emoções" seriam exclusivos do domínio familiar e, portanto, do âmbito privado, ao passo que o cuidado enquanto fazer/técnica estaria associado ao trabalho remunerado, próprio da esfera pública (Engel, 2020; Fietz, 2020; Hirata; Guimarães, 2012). É interessante notar como em relação às famílias de origem - vistas como tendo falhado em termos de suas obrigações morais e de afeto - essa "economia de afeto" serve como justificação potente na avaliação/controle e intervenção estatal. Por outro lado, transladado ao programa de famílias acolhedoras, o respeito pela "esfera privada" como âmbito de afeto supostamente fora do alcance do Estado opera como uma espécie de "blindagem", mantendo essas avaliações e esses controles à distância.

Interessante também pensar como são equacionadas as relações entre afetos, cuidados e lucro no contraponto entre as famílias acolhedoras e as famílias de origem. Conforme a visão moral dos "mundos hostis" (dinheiro e cuidado precisam ser mantidos separados, sobretudo no âmbito das famílias), o bom cuidado é baseado no amor desinteressado (Zelizer, 2012). Mas essa visão se traduz de forma variável conforme o lugar que ocupa a família na hierarquia moral. 
Os pedidos de ajuda financeira por parte das famílias acolhedoras, quando aparecem, são legitimados, pois no limite não visam o "lucro" e sim o "bom cuidado" da criança. Por outro lado, qualquer solicitação de ajuda financeira por parte das famílias de origem lhes coloca sob suspeição: o deles poderia ser um amor "interesseiro", visando benefício próprio.

O cuidado infantil e as controvérsias em torno do "bom" e o "mal cuidado" são temas que reaparecem nas reflexões de Nucci e Fazzioni (neste número) sobre as experiências de amamentação cruzada - isto é, de mulheres que amamentam os filhos de outras mulheres, ou porque estas não puderam amamentar (por problemas fisiológicos) ou para que possam seguir com suas vidas (trabalhar, estudar, etc.). Ao evocarem os debates que surgem em torno de uma policial em Belo Horizonte que amamenta um bebê enquanto a mãe deste é atendida na delegacia, as autoras revelam um cenário atravessado por fortes tensões envolvendo diferentes atores e mecanismos de regulação (morais, médicos, legislativos, econômicos, políticos e sociais).

A dualidade/paradoxo que envolve a amamentação cruzada é sintetizada pelas autoras na pergunta: ato de amor ou prática de risco? Parece simples, mas a equação se torna complexa à medida que nos questionamos sobre os sentidos que pode assumir o cuidado para os diferentes sujeitos, a partir da posição que ocupam na relação e, portanto, sempre de forma contingencial e localizada. O cuidado é contextual (não essencialista) e relacional, por isso mesmo que sua caracterização demanda muita atenção aos detalhes precisos de cada situação (Mol, 2008; Tronto, 2012). Do ponto de vista biomédico, como por exemplo do manual de boas práticas da OMS, a amamentação cruzada seria um "mau cuidado" que coloca a vida do bebê em risco, viola seus direitos. Do ponto de vista das mulheres, trata-se de um ato de amor, de garantir o melhor cuidado possível para as crianças que dependem delas. Seria possível pensar também que nessa equação de cuidado (bom ou mau), vê-se tanto "formas ostensivamente familiares" de cuidado (que são frequentemente objeto de julgamentos morais justamente porque escapam às tentativas de controle próprias das tecnologias de governo) quanto práticas mediadas por políticas institucionais e serviços públicos (como os bancos de leite) cujos modos de funcionamento são passíveis de controle e padronização institucional (Fonseca; Fietz, 2018).

A amamentação cruzada mobiliza redes de cuidados que são múltiplas (em termos das suas ramificações e agentes envolvidos) e desordenadas (do ponto 
de vista normativo e das políticas públicas) nos modos em que são tecidas. Envolvem relações simétricas, como bem pontuam as autoras, e de reciprocidade (cuja obrigação de retribuir pode inclusive ser adiada, aparecendo só muito tempo depois) (Bessin, 2016). Na outra ponta, temos a impessoalidade, as assimetrias, outras temporalidades e mediações nas formas de produzir vínculos e de retribuir cuidado.

São também essas ambiguidades entre o risco e o amor, entre o bom e o mau cuidado que atravessam a história da Andrielli com a qual começamos esta apresentação. A mãe que não pode amamentar a filha, ou seja, que não pode escolher a melhor forma de cuidar mesmo diante da recusa da bebê à fórmula que lhe administraram em lugar do leite materno, nos faz pensar: O que é feito/produzido em nome do cuidado dos sujeitos? Como os diferentes agentes agem em função das diversas concepções de cuidado? A mãe, por ser impedida de amamentar (por não poder ofertar à filha o que entende por "bom cuidado"), tem seus direitos violados, ao passo que a filha não tem direito ao leite materno, por entenderem que a mãe, em sua história pregressa, teria sido negligente (não oferecendo esse "bom cuidado"), violando os direitos de seus outros filhos.

Se são passíveis de serem borrados os limites entre o bom e o mau cuidado, o "binômio cuidado/não cuidado", cujos termos são "frequentemente tidos como dicotômicos, aparecem muitas vezes embaralhados", sobretudo quando se trata de experiências no âmbito da proteção da infância e adolescência (Lowenkron, 2016, p. 82). Esse é o caso da relação entre Marcela e seu filho Ricardo, que inspira o artigo de Efrem Filho e Mello (neste número) sobre as experiências de maternidade à luz dos constrangimentos de Estado. Não é por acaso que a "mãe" tem se tornado um operador ideal das políticas públicas, como bem destacam os autores. A esse lugar/posição de parentesco converge uma série de expectativas morais relacionadas em geral com afetos, emoções e, sobretudo, cuidado. Mas o que acontece "quando uma mãe renuncia a ser "mãe"?, se questionam os autores. Na esteira dessa renúncia, seguem-se muitas ameaças, mas uma em particular preocupa Marcela: poderia ela ser presa por não querer mais cuidar do filho mais velho, mesmo tendo esse filho lhe espancado? A "renúncia da mãe" remete a uma quebra de expectativa em relação à qualidade "natural" e "permanente" dessa entidade "mãe" e também em relação ao cuidado como qualidade "inata" das mulheres, em particular, das mães. 
Os estudos sobre cuidado têm insistido na problematização da associação entre trabalho de cuidado e gênero. Ainda que o trabalho do cuidado, remunerado ou não, diga respeito a toda sociedade, este tem sido tradicionalmente assumido pelas mulheres. E essa "naturalização das competências ditas femininas" também tem se apoiado, como lembra Bessin (2012), sobre uma relação com o tempo que atribui às mulheres uma disponibilidade temporal permanente às atividades de cuidado. A atitude de Marcela, ao romper com todas essas "premissas", não só representa a possibilidade de exercer certa agência diante dos controles postos pelas tecnologias de governo, como também desafia os entendimentos convencionais de gênero e cuidado.

Os modos pelos quais operam as tecnologias de governo, em um contexto de humanização do parto, são também tensionados pelas práticas de cuidado de doulas e educadoras perinatais, como observam Tempesta e França (neste número). Em meio a um conjunto conformado por instituições públicas e privadas, organizações profissionais (médicas/os, enfermeiras/os, etc.), saberes e técnicas biomédicas, normativas sobre parto e pós-parto, é que são tecidas essas teias complexas de cuidado que visam justiça reprodutiva. É em relação a tais tecnologias que muitas doulas se percebem e são percebidas pelos profissionais de saúde como os atores mais propensos a testemunhar essas experiências de violência. E esse cuidado, que é praticado através da escuta e de saberes alternativos acerca do parto e pós-parto, permite acionar o potencial de agência das mulheres atendidas. Ao narrarem o que vivenciam, através de um processo de legitimação do sofrimento pela escuta de outras mulheres, as parturientes encontram a possibilidade de se construírem enquanto sujeitos e agentes da sua própria experiência de parto (Fassin, 2004).

A prática da doulagem nos lembra que as experiências de cuidado são transformadoras não só para quem cuida e quem é cuidado, mas também incitam a transformação de um contexto e das formas pelas quais operam as tecnologias de governo em saúde reprodutiva. De modo que, no caso das experiências analisadas no artigo, essa transformação aponta para a emergência de uma pedagogia reprodutiva contra-hegemônica.

Seria possível pensar, a partir de um paralelo com as experiências no campo do serviço social francês analisadas por Bessin (2012), que há na doulagem um apelo para que se reconheça as temporalidades próprias do cuidado (ver também Fietz, 2020). Nessa linha de análise, podemos ver as experiências de 
violência obstétrica como reveladoras da tendência contemporânea do achatamento dos horizontes temporais do cuidado, à medida que reduzem ao tempo presente práticas que se inscrevem em temporalidades mais longas. Por outro lado, o trabalho das doulas permite colocar em prática uma lógica da temporalização própria ao cuidado de duas maneiras. Primeiro, lança mão de práticas baseadas em saberes tradicionais e/ou alternativos que priorizam o tempo próprio de cada mulher, o tempo do parto fisiológico e humanizado que não se conjuga com urgência e intervenções pontuais e medicalizadas. E, segundo, ao estimular esse exercício de narrar o sofrimento, a doulagem permite não só aliviar uma situação presente, mas também integra tal experiência num processo de reparação que se prolonga/estende no tempo. Ou seja, poderíamos pensar na doulagem como um trabalho de cuidado cujas ações/práticas são capazes de se inscrever na duração e se baseiam em grande medida sobre o passado dessas mulheres e nas situações por elas vivenciadas.

Terminamos nossa discussão (e também o próprio número temático) com o artigo de Rinaldi, Coitinho Filho, Souza e Souza que demonstra claramente como, para conseguirem realizar práticas de "bom cuidado", as pessoas não se submetem passivamente às orientações institucionais. Podem ignorar, podem negociar, ou podem se beneficiar das normas oficiais, mas sempre junto com estratégias criativas que lhes permitam realizar os cuidados que consideram apropriados para suas situações de família. Essa criatividade emerge com contornos nítidos na história de Geni, uma brasileira transexual de origem modesta que, junto com seu companheiro, assume desde cedo o papel de mãe para diferentes "meninos vulneráveis" que acolhe na sua casa. Percorrendo toda sua narrativa está o desejo não só de formar uma família, mas também de cuidar de crianças e jovens (alguns deles já na adolescência) necessitados.

Ao relatar suas experiências de maternidade ao longo de 30 anos, descrevendo a adoção ora informal, ora legal, de cinco filhos diferentes, deixa claro o quanto os mecanismos de governo influenciaram, sem determinar completamente, seus procedimentos. Quando, nos anos 1990, lhe foi negado qualquer reconhecimento oficial de sua identidade materna, ela simplesmente seguiu no cuidado de seus dois filhos, sem procurar mais o aval das autoridades. Já 20 e poucos anos depois, após uma série de mudanças - tanto no clima moral como nas orientações legislativas e políticas sociais -, a situação se inverteu. Agora, são os representantes do Estado que tomam a iniciativa de buscar Geni 
e seu companheiro para lhes sugerir a adoção de crianças de difícil colocação - isto é, de crianças mais velhas, negras ou com problemas de saúde que não são aceitas pela maioria de candidatas a pais adotivos. Para Geni, que passou a vida driblando as várias restrições impostas no seu comportamento familiar, o fato de a filiação legal de seus filhos ser atrelada à aceitação em lei da homoparentalidade (uma categoria com a qual ela não se identifica) parece de importância secundária.

Essa história nos remete, afinal, a uma noção que, desde seus primeiros anos, caminha junto com antropologia feminista da reprodução: a atenção especial à "ação transformativa" que pode ocorrer em lugares muito diferentes - de casas familiares a movimentos sociais e organizações instituídas (Ginsburg; Rapp, 1995). É nas histórias sobre cuidado que melhor vislumbramos os vários contradiscursos, as práticas alternativas e de resistência que estão constantemente se reatualizando com a possibilidade "não só de efetivar mudanças dramáticas, mas também de sustentar a vida cotidiana diante de condições difíceis causadas por guerra, doença, pobreza e desastres ecológicos" (Ginsburg; Rapp, 1995, p. 11, tradução nossa).

Devemos reconhecer, contudo, que não há nada intrinsecamente progressista nem linear nessas transformações. Os artigos deste número de Horizontes Antropológicos mostram claramente como, ao mesmo tempo que certos setores da população (incluindo, por exemplo, Geni) ganharam espaço nos últimos anos, outros (incluindo mulheres como Andrielli) têm sido acuados por mecanismos cada vez mais impositivos de intervenção nas suas vidas reprodutivas. Se desenvolvimentos tecnológicos (em particular, da biomedicina) parecem ter ampliado o leque de opções reprodutivas, por outro lado, muitas dessas tecnologias (de telefones celulares a orientações ginecológicas mundializadas) possibilitaram técnicas mais sutis, mas igualmente invasivas, de controle. E, se existem pessoas que, pelo seu poder aquisitivo ou mesmo através de alianças estratégicas, parecem se "libertar" dos controles institucionais, sempre surge a tendência das "resistências" se transformarem no novo normal com seus respectivos regimes morais também imperativos. Em paralelo à tensão entre os polos antagônicos de cuidado descrita acima (entre proteger e controlar), permanecem ambiguidades quanto à demarcação entre comportamentos "libertadores" e liberais, isto é, guiados por novos mercados de consumo e/ou ideais da economia neoliberal. 
Arguimos que essas tensões e essas ambiguidades se manifestam no mundo inteiro, mas aparecem com particular intensidade em regiões, como a América Latina, regidas pela desigualdade socioeconômica escancarada. É olhando para a complexidade de tais contextos que se torna evidente o quanto a reprodução hoje, longe de ser um processo meramente biológico, é uma questão política. Colocada dessa maneira, a noção de governança reprodutiva nos permite traçar as conexões, tal como recomendam Morgan e Roberts (2012), entre dinâmicas íntimas, políticas nacionais e lógicas econômicas globais, colocando em perspectiva e, quem sabe, ajudando a redesenhar os regimes morais que conectam corpos, biologias e subjetividades para que andem de forma consequente em direção à justiça reprodutiva.

A capa deste número de Horizontes Antropológicos é ilustrada com a imagem de um prato feito provavelmente na Itália no século XVI, cujo centro destaca a cena de um parto/nascimento, para a qual todas e todos voltam seus olhares e vigilância. No centro, é possível observar mulheres que cuidam de outras mulheres e também crianças; alguém que espia na porta (portanto fora do acontecimento, mas desejando nele penetrar) e uma mulher que apela aos deuses. No entorno dessa imagem central, vemos um universo mitológico e um apelo ao transcendental. Chama atenção como, já nesse momento, há elementos para reconsiderar, como sugerimos no texto em diálogo com Briggs (2017), a importância do papel de um conjunto de práticas/ações que por um longo período foi tomado como fundamentalmente pertencente à esfera privada, relegado à invisibilidade. $\mathrm{O}$ foco nesse acontecimento nos ajuda a refletir sobre o borramento das fronteiras entre os domínios privado e público que historicamente marcam a temática da reprodução. Dessa forma, ao elegermos essa imagem como capa do número sobre Governança Reprodutiva, partimos da hipótese de que toda reprodução é política (Ginsburg; Rapp, 1995) e, seguindo a trajetória de debates dos últimos anos, esperamos demonstrar que, tal como sugere Briggs (2017), "todas as políticas são políticas reprodutivas".

O Espaço Aberto deste número de Horizontes Antropológicos é dedicado ao centenário do livro Argonautas do Pacífico Ocidental de Bronislaw Malinowski, que será celebrado em 2022. Dando início às comemorações do próximo ano, Mariza Peirano e José Guilherme Cantor Magnani, em seus artigos, nos lembram dessa obra que se tornou não só um "divisor de águas na história da antropologia" como também uma "referência importante" para outras disciplinas 
das humanidades (linguística, sociologia e economia). No artigo "Argonautas, cem anos depois", Mariza Peirano nos inspira a pensar nos motivos pelos quais Argonautas é ainda hoje uma referência central para as ciências sociais. De forma interessante e renovada, ela nos conduz pelo percurso da obra, escrita em quatro meses, e pela trajetória de seu criador, que era "professor carismático", "conferencista magnético" e dono de uma "personalidade poderosa". Em seu livro mais conhecido, Malinowski nos faz pensar que "a teoria é par indissociável da etnografia" e desafia as futuras gerações a elaborarem "teorias etnográficas". Ainda que, em períodos alternados, tenha sido aplaudido e objeto de muitas críticas, Argonautas se tornou um clássico sobretudo por se constituir enquanto precursor da pesquisa de campo intensiva e por "alimentar ideias e utopias". Assim como Peirano, Magnani no artigo "Argonautas, cem anos: uma releitura em pesquisas do Núcleo de Antropologia Urbana da USP" nos convida a empreender um cuidadoso resgate da contribuição de Argonautas para a prática etnográfica. Na ocasião do seu centenário, Magnani nos guia pela releitura dos achados de Malinowski nas Ilhas Trobriand, tendo em vista a realidade atual, quando os temas de pesquisa têm também como recorte a dinâmica das grandes cidades contemporâneas. Tendo como base as pesquisas e experimentos dos pesquisadores e das pesquisadoras do Laboratório do Núcleo de Antropologia Urbana da USP (LabNAU), Magnani se dedica a pensar nas novas abordagens que a obra suscita. Como forma de fugir dos "lugares comuns" frequentemente acionados quando se trata do legado de Malinowski, Magnani encontra ali elementos que permitem reafirmar a centralidade da pesquisa de campo, com base em dados já existentes de estudos anteriores, e a própria reinvenção da etnografia em tempos pandêmicos.

O Espaço Aberto deste número de Horizontes Antropológicos também celebra os 25 anos da fotoetnografia com uma entrevista com Luiz Eduardo Robinson Achutti, professor do Instituto de Artes da UFRGS, que obteve o grau de mestre no Programa de Pós-Graduação em Antropologia Social da UFRGS no qual lecionou até 2014. Em 2021, ano que celebramos a emergência desse campo na antropologia visual, Achutti nos fala da sua trajetória profissional e acadêmica e nos fornece um panorama dos aspectos teóricos e metodológicos da fotoetnografia. A entrevista, realizada por Fabio Lopes Alves, Claudia Barcelos de Moura Abreu, Tânia Maria Rechia Schroeder e Adrian Alvarez Estrada, nos revela ainda, nesse diálogo com Achutti, quais são os desafios e perspectivas desse "conceito" para os próximos 25 anos. 


\section{Referências}

ALLEBRANDT, D. Quem precisa preservar a fertilidade? Gênero, tecnologia e mercado na Reprodução Assistida. In: ROHDEN, F.; PUSSETTI, C.; ROCA, A. (org.). Biotecnologias, transformações corporais e subjetivas: saberes, práticas e desigualdades. Brasília: ABA Publicações, 2021. p. 113-131.

ALVAREZ, B.; MARRE, D. Motherhood in Spain: from the "Baby Boom" to "Structural Infertility”. Medical Anthropology, [s. l.], 9 Aug. 2021. Ahead of print. DOI: https://doi. org/10.1080/01459740.2021.1961246.

BALLARD, R. L. et al. (ed.). The intercountry adoption debate: dialogues across disciplines. Newcastle upon Tyne: Cambridge Scholars Publishing, 2015.

BARROSO, C.; CORREA, S. Public servants, professionals, and feminists: the politics of contraceptive research in Brazil. In: GINSBURG, F. D.; RAPP, R. (ed.). Conceiving the New World Order: the global politics of reproduction. Berkeley: University of California Press, 1995. p. 292-307.

BESSIN, M. Postface “Les tensions temporelles de la protection”. In: GUIMARD, N.; PETIT-GATS, J. Le contrat jeune majeur: un temps négocié. Paris: L’Harmattan, 2011. p. 180-190.

BESSIN, M. Politiques de la présence: les enjeux temporels et sexués du care dans le travail social. In: GARRAU, M.; LE GOF, A. (dir.). Politiser le care?: perspectives sociologiques et philosophiques. Paris: Le Bord de l'Eau, 2012. p. 41-58. Disponível em: https://hal.archives-ouvertes.fr/hal-03007330/document. Acesso em: 4 nov. 2021.

BESSIN, M. Política da presença: as questões temporais e sexuadas do cuidado. In: ABREU, A.; HIRATA, H.; LOMBARDI, M. R. Gênero e trabalho no Brasil e França: perspectivas interseccionais. São Paulo: Boitempo, 2016. p. 235-245.

BIRENBAUM-CARMELI, D.; INHORN, M. (ed.). Assisting reproduction, testing genes: global encounters with new biotechnologies. New York: Berghahn Books, 2009.

BOTTAMEDI, F. Bebê retirada da mãe em Florianópolis é internada com problemas respiratórios. ND+, [s. l.], 21 ago. 2021. Disponível em: https://ndmais.com.br/saude/ bebe-retirada-da-mae-em-florianopolis-e-internada-com-problemas-respiratorios/. Acesso em: 4 nov. 2021.

BRIGGS, L. How all politics became reproductive politics: from welfare reform to foreclosure to Trump. Berkeley: University of California Press, 2017.

CARDARELLO, A. O interesse da criança e o interesse das elites: escândalos de tráfico de crianças", adoção e paternidade no Brasil. Scripta Nova, [s l.], v. 16, n. 395, 2012. 
CASANOVA, E. M. de; BRITES, J. G. Apresentação Dossiê Trabalho, Cuidado e Emoções. Século XXI: revista de ciências sociais, [s. l.], v. 9, n. 3, p. 709-719, 2019. Disponível em: https://periodicos.ufsm.br/seculoxxi/article/view/48494. Acesso em: 4 nov. 2021.

CASTRO, A.; SAVAGE, V. Obstetric violence as reproductive governance in the Dominican Republic. Medical Anthropology, [s l.], v. 38, n. 2, p. 123-136, 2019.

COLEN, S. "Like a mother to them": stratified reproduction and West Indian childcare workers and employers in New York. In: GINSBURG, F. D.; RAPP, R. (ed.). Conceiving the New World Order: the global politics of reproduction. Berkeley: University of California Press, 1995. p. 78-102.

CONSTABLE, N. The commodification of intimacy: marriage, sex, and reproductive labor. Annual Review of Anthropology, [s l.], v. 38, p. 49-64, 2009.

COOPER, M.; WALDBY, C. Clinical labor: tissue donors and research subjects in the global bioeconomy. Durham: Duke University Press, 2014.

CORNEJO-VALLE, M.; PICHARDO, J. I. La “ideología de género" frente a los derechos sexuales y reproductivos. El escenario español. Cadernos Pagu, Campinas, n. 50, e175009, 2017.

CORREAA, M. C; LOYOLA, M. A. Tecnologias de reprodução assistida no Brasil: opções para ampliar o acesso. Physis, Rio de Janeiro, v. 25, n. 3, p. 753-777, 2015.

COURDURIÈS, J.; HERBRAND, C. Genre, parenté et techniques de reproduction assistée: bilan et perspectives après 30 ans de recherche. Enfances, familles, générations, [s. l.], n. 21, p. xxviii-xliv, 2014.

CRUZ RIFIOTIS, F.; RIFIOTIS, T. Conselho Tutelar como tecnologia de governo: relações agonísticas entre proteção e vigilância. Runa: archivo para las ciencias del hombre, [s. l.], v. 40, n. 2, p. 239-256, 2019.

DESY, A.; MARRE, D. Reproductive exclusion: French clients undergoing cross-border reproductive care in Barcelona. In: GUERZONI, C.; MATTALUCCI, C. (ed.). Body politics and reproductive governances: "flesh", technologies and knowledge. Bingley: Emerald Group Publishing, 2021. No prelo.

ENGEL, C. Partilha e cuidado das demências: entre interações medicamentosas e rotinas. 2020. Tese (Doutorado em Antropologia) - Universidade de Brasília, Brasília, 2020.

FAIRCLOTH, C. Militant lactivism?: attachment parenting and intensive motherhood in the UK and France. New York: Berghahn Books, 2013.

FASSIN, D. Des mauxindicibles: sociologie des lieux d'écoute. Paris: La Découverte, 2004. 
FASSIN, D. Another politics of life is possible. Theory, Culture \& Society, [s. l.], v. 29, p. 44-60, 2009.

FIETZ, H. Construindo futuros, provocando o presente: cuidado familiar, moradias assistidas e temporalidades na gestão cotidiana da deficiência intelectual no Brasil. 2020. Tese (Doutorado em Antropologia Social) - Instituto de Filosofia e Ciências Humanas, Universidade Federal do Rio Grande do Sul, Porto Alegre, 2020.

FINAMORI, S.; SILVA, A. B. M. Identidade e pertencimento: grupos de apoio à adoção e direito às origens. Sexualidad, Salud y Sociedad, Rio de Janeiro, n. 33, p. 295-317, 2019.

FONSECA, C. Tecnologías globales de la moralidad materna: políticas de educación para la primera infancia en Brasil contemporáneo. In: COSSE, I. et al. (ed.). Infancias: políticas y saberes en Argentina y Brasil. Siglos XIX y XX. Buenos Aires: Editorial Teseo, 2012. p. 175-204.

FONSECA, C. Crianças, seus cérebros... e além: reflexões em torno de uma ética feminista de pesquisa. Revista Estudos Feministas, Florianópolis, v. 27, n. 2, e56169, 2019.

FONSECA, C.; FIETZ, H. Collectives of care in the relations surrounding people with "head troubles": family, community and gender in a working-class neighbourhood of southern Brazil. Sociologia \& Antropologia, Rio de Janeiro, v. 8, n. 1, p. 223-243, 2018.

FREITAS, J. “Designer babies não são futurísticos, eles já estão aqui”: os testes genéticos pré-implantacionais e o futuro como prática situada de materialização. In: ROHDEN, F.; PUSSETTI, C.; ROCA, A. (org.). Biotecnologias, transformações corporais e subjetivas: saberes, práticas e desigualdades. Brasília: ABA Publicações, 2021. p. 83-112.

GILLIES, V.; EDWARDS, R.; HORSLEY, N. Challenging the politics of early intervention: who's 'saving' children and why. Bristol: Policy Press, 2017.

GINSBURG, F.; RAPP, R. The politics of reproduction. Annual Review of Anthropology, [s. l.], v. 20, p. 311-343, 1991.

GINSBURG, F.; RAPP, R. (ed.). Conceiving the New World Order: the global politics of reproduction. Berkeley: University of California Press, 1995.

GOMES, J. (coord.). Primeira infância e maternidade nas ruas de São Paulo. São Paulo: Lampião Conteúdo e Conhecimento, 2017.

GROSSI, M. P.; OLTRAMARI, L. C.; FERREIRA, V. K. (org.). Família, gênero e memória: diálogos interdisciplinares entre França e Brasil. Brasília: ABA; Florianópolis: Tribo da Ilha, 2021. 
GROSSI, M. P.; PORTO, R.; TAMANINI, M. (org.). Novas tecnologias reprodutivas conceptivas: questões e desafios. Brasília: Letras Livres, 2003.

GUIMARÃES, P. Jovem preta é afastada de bebê após nascimento em maternidade de Florianópolis. Catarinas, [s. l.], 30 jul. 2021. Disponível em: https://catarinas.info/ jovem-preta-e-afastada-de-bebe-apos-nascimento-em-maternidade-de-florianopolis/. Acesso em: 4 nov. 2021.

HAN, S.; TOMORI, C. The Routledge handbook of anthropology and reproduction. London: Routledge, 2021.

HIRATA, H.; DEBERT, G. G. Apresentação Dossiê Gênero e Cuidado. Cadernos Pagu, Campinas, n. 46, p. 7-15, 2016.

HIRATA, H.; GUIMARÃES, N. A. (org.). Cuidado e cuidadoras: as várias faces do trabalho do care. São Paulo: Atlas, 2012.

HIRATA, H.; MOLINIER, P. Les ambiguïtés du care. Travailler, [s. l.], n. 28, p. 9-13, 2012. Disponível em: https://www.cairn.info/revue-travailler-2012-2-page-9.htm?try_ download=1. Acesso em: 4 nov. 2021.

KRAUSE, E. L.; DE ZORDO, S. Introduction. Ethnography and biopolitics: tracing 'rationalities' of reproduction across the north-south divide. Anthropology \& Medicine, [s. l.], v. 19, n. 2, p. 137-151, 2012.

LEINAWEAVER, J.; SELIGMANN, L. Introduction: cultural and political economies of adoption in Latin America. Journal of Latin American and Caribbean Anthropology, [s. l.], v. 14, n. 1, p. 1-19, 2009.

LLOBET, V.; MILANICH, N. La maternidad y las mujeres de sectores populares en las Transferencias Condicionadas de Ingresos. Un aporte al debate sobre el cuidado y las relaciones de género. Zona Franca: revista del Centro de Estudios Interdisciplinarios sobre Mujeres, Rosario, v. 22, p. 58-69, 2014.

LOWENKRON, L. As várias faces do cuidado na cruzada antipedofilia. Anuário Antropológico, Brasília, v. 41, n. 1, p. 81-98, 2016. Disponível em: https://periodicos.unb.br/ index.php/anuarioantropologico/article/view/6482. Acesso em: 4 nov. 2021.

LUNA, N. Provetas e clones: uma antropologia das novas tecnologias reprodutivas. Rio de Janeiro: Fiocruz, 2007.

MACVARISH, J. Neuroparenting: the expert invasion of family life. London: Palgrave \& Macmillan, 2016. 
MARRE, D.; BRIGGS, L. International adoption: global inequalities and the circulation of children. New York: New York University Press, 2009.

MARRE, D.; SAN ROMÁN, B.; GUERRA, D. On reproductive work in Spain: transnational adoption, egg donation, surrogacy. Medical Anthropology, [s. l.], v. 37, n. 2, p. 158$173,2018$.

MEMMI, D. Faire vivre et laisser mourir: le gouvernement contemporain de la naissance et de la mort. Paris: La Découverte, 2003.

MODELL, J. Rights to the children: foster care and social reproduction in Hawai'i. In: FRANKLIN, S.; RAGONÉ, H. (ed.). Reproducing reproduction: kinship, power, and technological innovation. Philadelphia: University of Pennsylvania Press, 1998. p. 156-172.

MOL, A. The logic of care: health and the problem of patient choice. London: Routledge, 2008.

MORGAN, L. M.; ROBERTS, E. F. S. Reproductive governance in Latin America. Anthropology \& Medicine, [s. l.], v. 19, n. 2, p. 241-254, 2012.

MURPHY, M. Seizing the means of reproduction: entanglements of feminism, health, and technoscience. Durham: Duke University Press, 2012.

NASCIMENTO, P. F. G. Desejo de filhos: uma etnografia sobre reprodução, desigualdade e políticas de saúde. João Pessoa: Editora da UFPB, 2020.

PAPERMAN, P. Care, sensibilité, vulnérabilité: Les gens vulnérables n'ont rien d'excepcionnel. In: PAPERMAN, P.; LAUGIER, S. (dir.). Le souci des autres: éthique et politique du care. Nouvelle édition [en ligne]. Paris: Éditions de l'École des Hautes Études en Sciences Sociales, 2011.

PAPERMAN, P.; LAUGIER, S. (dir.). Le souci des autres: éthique et politique du care. Nouvelle édition [en ligne]. Paris: Éditions de l'École des Hautes Études en Sciences Sociales, 2011.

RAMIREZ-GALVEZ, M. Corpos fragmentados e domesticados na reprodução assistida. Cadernos Pagu, Campinas, n. 33, p. 83-115, 2009.

RINALDI, A. A. Adoção: políticas para a infância e juventude no Brasil? Sexualidad, Salud y Sociedad, Rio de Janeiro, v. 33, p. 273-294, 2019.

ROBERTS, D. Shattered bonds: the color of child welfare. New York: Basic Civitas Books, 2002. 
ROHDEN, F. Adjusting hormones and constructing desires: new materialisations of female sexuality in Brazil. Culture Health \& Sexuality, [s. l.], v. 1, p. 1-14, 2019.

ROHDEN, F; MONTEIRO, M. Para além da ciência e do anthropos: deslocamentos da antropologia da ciência e da tecnologia no Brasil. BIB: revista brasileira de informação bibliográfica em ciências sociais, São Paulo, v. 1, p. 1-33, 2019.

ROSE, N.; VALVERDE, M. Governed by Law? Social Legal Studies, [s. l.], v. 7, n. 4, p. 541$551,1998$.

ROSTAGNOL, S. Aborto e democracia. Brasília: Alameda Casa Editorial, 2015.

ROSTAGNOL, S. Aborto voluntario y relaciones de género: políticas del cuerpo y de la reproducción. Montevideo: CSIC, 2016.

RUSSO, J.; NUCCI, M. F. Dando à luz a um novo cérebro? Discursos científicos e leigos sobre mudanças cerebrais na gestação e na maternidade. In: ROHDEN, F.; PUSSETTI, C.; ROCA, A. (org.). Biotecnologias, transformações corporais e subjetivas: saberes, práticas e desigualdades. Brasília: ABA Publicações, 2021. p. 25-52.

SANABRIA, E. From sub- to super-citizenship: sex hormones and the body politic in Brazil. Ethnos, [s. l.], v. 75, n. 4, p. 377-401, 2010.

SARCINELLI, A. Os limites do conceito de família na Itália: processos de kinning e de-kinning em configurações familiares homoparentais. In: FONSECA, C.; MEDAETS, C.; RIBEIRO, F. (org.). Pesquisas sobre família e infância no mundo contemporâneo. Porto Alegre: Sulina, 2018. p. 23-40.

SARGENT, C.; BROWNER, C. (ed.). Globalization, reproduction and the state. Durham: Duke University Press, 2011.

SARMENTO, C. S. "Por que não podemos ser mães?": tecnologias de governo, maternidade e mulheres com trajetória de rua. 2020. Dissertação (Mestrado em Antropologia Social) - Instituto de Filosofia e Ciências Humanas, Universidade Federal do Rio Grande do Sul, Porto Alegre, 2020.

SELMAN, P. Tendencias globales en adopción internacional: ¿en el "interés superior de la infancia"? Scripta Nova, [s. l.], n. 16, 2012 Disponível em: http://www.ub.edu/geocrit/sn/sn-395/sn-395-21.htm. Acesso em: 4 nov. 2021.

SESIA, P. Naming, framing and shaming through obstetric violence. An initial approach to the judicialization of maternal health rights violations in Mexico. In: GIBBON, S. et al. Critical medical anthropology: perspectives in and from Latin America. London: UCL Press, 2020. p. 222-247. 
STRAW, C. et al. Reprodução assistida e relações de gênero na América Latina. Curitiba: Editora CRV, 2016.

TAMANINI, M. Maternidades são políticas: da fecundidade, dos especialistas, das mulheres, dos laboratórios, das tecnologías e muito mais. In: VOSNE MARTINS, A. P.; ARIAS GUEVARA, M. (org.). Políticas de gênero na América Latina: aproximações, diálogos e desafios. Jundiaí: Paco, 2015. p. 171-196.

TARNOVSKI, F. Parentalidade e gênero em famílias homoparentais francesas. Cadernos Pagu, Campinas, n. 40, p. 67-93, 2013.

TRONTO, J. Le risque ou le care? Trad. Fabienne Brugère. Paris: Presses Universitaires de France, 2012.

UZIEL, A. P. Homossexualidade e adoção. Rio de Janeiro: Garamond, 2007.

VAN WICHELEN, S. Moving children through private international law: institutions and the enactment of ethics. Law \& Society Review, [s. l.], v. 53, n. 3, p. 671-705, 2019.

VIERA CHERRO, M. Género y biocapitalismo: economía política de la "donación" de gametos en Uruguay. 2019. Tesis (Doctorado en Antropología) - Faculdad de Humanidades y Ciências de la Educación, Universidad de la República, Montevideo, 2019.

VILLALTA, C. Entregas y secuestros: el rol del Estado en la apropiación de niños. Buenos Aires: Editorial Del Puerto, 2012.

VITULE, C.; FACHIN, R.; COUTO, M. Práticas reprodutivas lésbicas: reflexões sobre genética e saúde. Ciência \& Saúde Coletiva, Rio de Janeiro, v. 22, n. 12, p. 4031-4040, 2016.

ZELIZER, V. A economia do care. In: HIRATA, H.; GUIMARÃES, N. A. (org.). Cuidado e cuidadoras: as várias faces do trabalho do care. São Paulo: Atlas, 2012. p. 15-28. 